such complicating factors as variable absorption or distribution.

Two important features emerge from this study. Firstly, our findings confirm observations ${ }^{1011}$ of an age-related decline in microsomal oxidation rates in man. Secondly, they show that in a population exhibiting this decline acetylation does not change with age. Thus, there are pharmokinetic grounds in the elderly for reducing the dose of drugs that are metabolised by oxidation, but this does not seem to apply to drugs metabolised by acetylation. Indeed, in so far as the latter pathway is concerned, not only was there no observed difference in acetylator phenotype in the two groups but there was also no apparent difference within the phenotypes, or in antimodes between the populations. These findings do not therefore support the hypothesis that heterozygotes for acetylation have a survival advantage to old age. Nor do they support the hypothesis that there is a general decline of liver function with advancing age in man. ${ }^{1 \times}$

We thank Mrs L Pulmann and Mr D B Henderson for technical help; Dr A J Cassells-Smith and the department of clinical biochemistry, Newcastle General Hospital, for undertaking the routine laboratory investigations; colleagues in the department of geriatric medicine, Newcastle General Hospital; and the Newcastle Area Health Authority (Teaching) for financial support.

\section{References}

1 Smith, S E, and Rawlins, M D, V'ariability in Human Drug Response. London, Butterworth, 1973.

2 Whittaker, J A, and Evans, D A P, British Medical fournal, 1970, 4, 323

3 Åsberg, M, et al, British Medical fournal, 1970, 4, 18

- Kutl, H, et al, Archives of Neurology, 1964, 11, 642.

' Evans, D A P, Manley, K A, and McKusick, V A, British Medical fournal, $1960,42,485$

' Seidl, L G, et al, Bulletin of the fohns Hopkins Hospital, 1966, 119, 299.

i Hurwitz, N, British Medical fournal, 1969, 1, 549.

${ }^{8}$ Evans, J G, and Jarvis, E H, British Medical fournal, 1972, 4, 487.

${ }^{9}$ Rawlins, M D, British Medical fournal, 1974, 4, 91.

${ }^{10}$ O'Malley, K, et al, British Medical fournal, 1971, 3, 607.

${ }^{11}$ Vestal, R E, et al, Clinical Pharmacology and Therapeutics, 1975, 18, 425.

12 Javitt, N B, in Diseases of the Liver, ed L Schiff, p 111. Philadelphia, Lippincott, 1975.

${ }^{13}$ Maher, J T, et al, American Review of Tuberculosis and Pulmonary Diseases, 1957, 76, 852

14 Henderson, D B, unpublished.

15 Cunningham, J L, Bullen, M F, and Evans, D A P, European fournal of Clinical Pharmacology, 1974, 7, 461.

16 Taylor, W, Batchelor of Medical Sciences thesis. University of Newcastle upon Tyne, 1976

1: Mitchell, J R, Clinical Pharmacology and Therapeutics, 1975, 18, 70.

is Skaunic, V, Nerad, V, and Skaunicova, J, Gerontologia Clinica, 1968, 10, 43

(Accepted 11 May 1977)

\title{
Growth hormone, insulin, and prolactin secretion in anorexia nervosa and obesity during bromocriptine treatment
}

\author{
A D B HARROWER, P L YAP, ISOBEL M NAIRN, H J WALTON, J A STRONG, A CRAIG
}

British Medical fournal, 1977, 2, 156-159

ginally raised in two obese subjects, fell significantly in both groups during treatment. We observed no consistent weight changes in either group.

\section{Summary}

We studied secretion of growth hormone (GH), insulin, and prolactin in eight women with anorexia nervosa and nine women with refractory obesity before and during treatment with bromocriptine, $10 \mathrm{mg} / \mathrm{day}$.

In the anorexic patients the raised plasma GH concentrations occurring during an oral glucose tolerance test fell significantly while on bromocriptine treatment, but there was no change in plasma insulin or blood glucose concentrations. In the obese patients, however, plasma GH concentrations remained low during the oral glucose tolerance test, and were not modified by bromocriptine. Blood glucose and plasma insulin concentrations were also unchanged. Plasma GH and plasma 11-hydroxycorticosteroid responses to insulin-induced hypoglycaemia were unaffected. Serum prolactin concentrations which were raised in five anorexic patients and mar-

Metabolic Unit, Departments of Medicine and Psychiatry, Western General Hospital, Edinburgh EH4 2XU

A D B HARROWER, MRCP, senior registrar

$P$ L YAP, MB, CHB, senior house officer

ISOBEL M NAIRN, BSC, senior biochemist, metabolic unit

H J WALTON, MD, FRCPSYCH, professor and head of department of psychiatry

J A STRONG, MD, FRCP, professe $r$ of medicine and consultant physician

Searle Diagnostic, High Wycombe, Bucks HP12 4HL

A CRAIG, PHD, divisional manager, medical laboratory services

\section{Introduction}

Bromocriptine raises the blood concentration of growth hormone $(\mathrm{GH})$ in normal subjects, ${ }^{1}$ while depressing the raised concentrations of $\mathrm{GH}$ in patients with acromegaly." 3 Most patients with anorexia nervosa have raised fasting concentrations of $\mathrm{GH}$ that fail to decrease during an oral glucose tolerance test, and may indeed show a paradoxical rise as in some cases of acromegaly. In obesity, however, plasma GH concentrations are low $^{5}$ and do not show the post-absorptive peak seen in normal subjects. ${ }^{6}$ These anomalous GH responses prompted us to study the effect of bromocriptine on $\mathrm{GH}$ and insulin secretion in patients with anorexia nervosa and refractory obesity.

Serum prolactin concentrations have been reported to be normal $^{*}{ }^{*}$ or increased ${ }^{9}$ in patients with anorexia nervosa, but there is no information about prolactin concentrations in obese people. We therefore also investigated the effect of bromocriptine on serum prolactin concentrations in both conditions. We monitored the weights of both groups of patients closely since some overweight patients with galactorrhoea have been shown to revert to their normal weight while on treatment with bromocriptine. ${ }^{11}$

\section{Patients and methods}

We studied eight women with typical anorexia nervosa. Six of them were under our care for the first time, and two (cases 1 and 2) had 
already undergone treatment in the department of psychiatry for six weeks (table I). None of the patients was receiving or had received any drugs at the time of the initial investigation or for at least four weeks beforehand. Nine women patients, each of whom exceeded her standard weight by more than $25^{\circ}$, formed the obese group.

Despite continuous supervision of diet the weights of these patients had remained unchanged for at least a year (table II). The nature of the investigation was fully explained to each patient and all those approached agreed to participate. We took a dietary history from patients (tables I and II), but did not try to modify their diet during treatment with bromocriptine.

Patients were admitted to the metabolic unit, and after an overnight fast a butterfly needle (Abbott) was inserted into a forearm vein 30 minutes before taking a baseline sample; the needle was kept patent with heparinised saline. An oral glucose load of $50 \mathrm{~g}$ was then given
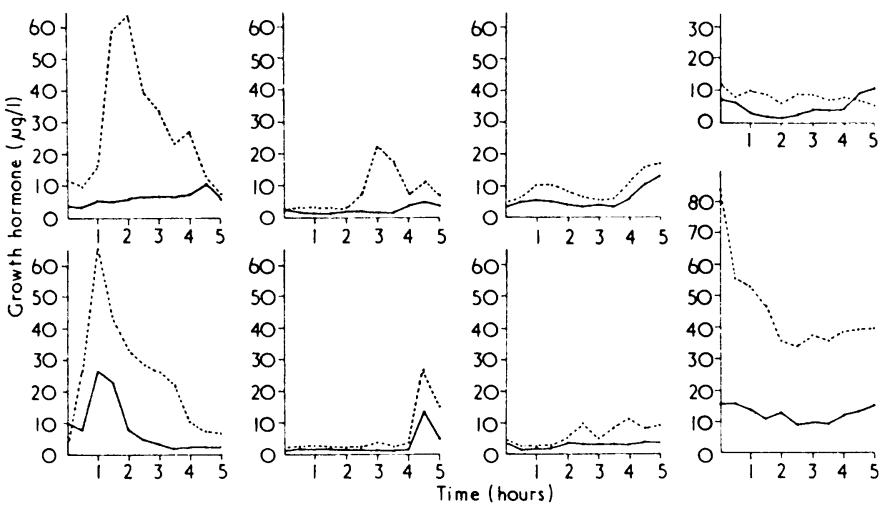

FIG 1-Plasma growth hormone concentrations during an oral glucose tolerance test in eight women patients with anorexia nervosa before (dashed line) and during (solid line) treatment with bromocriptine $10 \mathrm{mg} /$ day. and blood was taken into heparinised tubes at 30-minute intervals for five hours. Plasma was separated immediately and stored at $-20^{\circ} \mathrm{C}$ for assay later. In the obese patients only, after a further overnight fast and when a baseline blood sample had been obtained, each patient was given soluble insulin $(0 \cdot 15 \mathrm{U} / \mathrm{kg})$ intravenously. Further samples of blood were taken after 10, 20,30, 45, 60, 90, and 120 minutes. Blood glucose was estimated by the Technicon autoanalyser using a glucoseoxidase method. ${ }^{11}$ Plasma 11-hydroxycorticosteroid concentrations (11-OHCS) were measured by fluorometry. ${ }^{12}$ Plasma $\mathrm{GH}^{13}$ and insulin $^{14}$ concentrations and serum prolactin ${ }^{15}$ concentrations were estimated by specific radioimmunoassay.

Treatment was then started with bromocriptine, initially $2.5 \mathrm{mg}$ once daily with food, increasing by $2.5 \mathrm{mg} /$ day at intervals of three days to a maximum of $10 \mathrm{mg} /$ day in four divided doses. The anorexic patients remained in hospital and were studied two weeks after they had been established on a daily dose of $10 \mathrm{mg}$ of bromocriptine. The obese patients were readmitted and the investigations repeated after they had been treated as outpatients for four weeks. Thereafter they remained on treatment with bromocriptine for three months and were seen at intervals of two weeks or less; they were weighed at each visit and we asked them about any possible side effects from the drug.

\section{Results}

\section{ANOREXIA NERVOSA}

Figure 1 shows the $\mathrm{GH}$ values during the oral glucose tolerance test for each patient before and during treatment with bromocriptine. For each patient the concentrations of $\mathrm{GH}$ during treatment were lower than before, and the higher the concentrations before treatment the greater the fall. During treatment with bromocriptine, plasma $\mathrm{GH}$ concentrations were significantly lower from one to four hours after the oral glucose tolerance test. There was no change in blood glucose or plasma insulin concentrations during the test (fig 2). Prolactin concentrations were raised initially in five out of the eight patients, and fell during treatment in the whole group $(P<0.05$; table I and fig 3 ).

TABLE I-Clinical details of eight women patients with anorexia nervosa, including weight change during study and serum prolactin concentrations before and during treatment with bromocriptine. Daily energy intake was estimated from patients' histories

\begin{tabular}{|c|c|c|c|c|c|c|c|c|c|}
\hline \multirow{2}{*}{ Patient } & \multirow{2}{*}{$\underset{\text { (years) }}{\text { Age }}$} & \multirow{2}{*}{$\underset{(\mathrm{cm})}{\text { Height }}$} & \multirow{2}{*}{$\underset{(\mathbf{k g})}{\text { Weight }}$} & \multirow{2}{*}{ 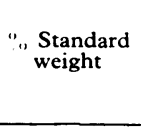 } & \multirow{2}{*}{$\begin{array}{l}\text { Weight } \\
\text { change } \\
(\mathrm{kg})\end{array}$} & \multirow{2}{*}{$\begin{array}{c}\text { Duration of } \\
\text { illness } \\
\text { (years) }\end{array}$} & \multirow{2}{*}{$\begin{array}{c}\text { Energy } \\
\text { intake } \\
(\mathrm{MJ} / \text { day })\end{array}$} & \multicolumn{2}{|c|}{$\begin{array}{c}\text { Serum prolactin } \\
(\mu \mathbf{g} / \mathbf{l})\end{array}$} \\
\hline & & & & & & & & $\begin{array}{c}\text { Before } \\
\text { treatment }\end{array}$ & $\underset{\text { Dreatment }}{\text { During }}$ \\
\hline $\begin{array}{l}1 \\
2 \\
3 \\
4 \\
5 \\
6 \\
7 \\
8\end{array}$ & $\begin{array}{l}17 \\
22 \\
20 \\
22 \\
36 \\
15 \\
21 \\
24\end{array}$ & $\begin{array}{l}163 \\
153 \\
167 \\
160 \\
167 \\
162 \\
161 \\
162\end{array}$ & $\begin{array}{l}41 \cdot 4 \\
33 \cdot 2 \\
43 \cdot 4 \\
37 \cdot 5 \\
36 \cdot 2 \\
45 \cdot 8 \\
46 \\
31 \cdot 4\end{array}$ & $\begin{array}{l}74 \\
60 \\
72 \cdot 5 \\
68 \cdot 3 \\
56 \\
88 \\
76 \\
55\end{array}$ & $\begin{array}{l}\text { Nil } \\
\text { Nil } \\
+0.8 \\
+2.5 \\
-2.1 \\
-0.4 \\
+2.9 \\
+2.4\end{array}$ & $\begin{array}{l}0 \cdot 25 \\
5 \\
1 \cdot 5 \\
2 \cdot 75 \\
4 \\
1 \\
1 \cdot 5 \\
0 \cdot 5\end{array}$ & $\begin{array}{c}0.4 \\
\text { NA } \\
4 \cdot 6 \\
6.9 \\
3 \cdot 1 \\
4.3 \\
\text { NA } \\
3.5\end{array}$ & $\begin{array}{l}12 \\
90 \\
20 \\
20 \\
17 \\
15 \\
21 \\
11\end{array}$ & $\begin{array}{c}<2.5 \\
<2.5 \\
4 \\
<2.5 \\
4 \\
<2.5 \\
3 \\
3.2\end{array}$ \\
\hline & & & & & & & & $26.9 *$ & $3+0.2^{*}$ \\
\hline
\end{tabular}

* Mean values $S E$ of mean

Conversion: SI to traditional umits-Serum prolactin $1 \mu \mathrm{g}, \mathrm{l}=1 \mathrm{ng} / \mathrm{ml}$ (reference range 3-16 $\mu \mathrm{g} / \mathrm{l}$ ); energy intake $1 \mathrm{MJ} \approx 239 \cdot 2 \mathrm{kcal}$.

TABLE II-Clinical details of nine women patients with refractory obesity who were treated with bromocriptine. Weight change was estimated after three months' treatment

\begin{tabular}{|c|c|c|c|c|c|c|c|}
\hline \multirow{2}{*}{ Patient } & \multirow{2}{*}{$\underset{\text { (years) }}{\text { Age }}$} & \multirow{2}{*}{$\underset{(\mathrm{kg})}{\text { Weight }}$} & \multirow{2}{*}{ 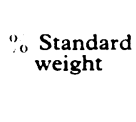 } & \multirow{2}{*}{$\underset{(\mathbf{k g})}{\text { Weight change }}$} & \multirow{2}{*}{$\begin{array}{c}\text { Estimated energy } \\
\text { intake } \\
(\mathrm{MJ} / \text { day })\end{array}$} & \multicolumn{2}{|c|}{$\underset{(\mu \mathrm{g} / \mathbf{l})}{\operatorname{Serum} \text { prolactin }}$} \\
\hline & & & & & & $\begin{array}{c}\text { Before } \\
\text { treatment }\end{array}$ & $\begin{array}{c}\text { During } \\
\text { treatment }\end{array}$ \\
\hline $\begin{array}{l}1 \\
2 \\
3 \\
4 \\
5 \\
6 \\
6 \\
7 \\
8 \\
9\end{array}$ & $\begin{array}{l}30 \\
45 \\
33 \\
44 \\
41 \\
35 \\
36 \\
38 \\
36\end{array}$ & $\begin{array}{c}90.9 \\
124 \\
94.5 \\
82.7 \\
132 \\
80.5 \\
95.9 \\
96.1 \\
107.3\end{array}$ & $\begin{array}{l}180 \\
208 \\
148 \\
142 \\
215 \\
146 \\
150 \\
163 \\
190\end{array}$ & $\begin{array}{l}\mathrm{Nil} \\
+2.3 \\
+1.8 \\
+2.4 \\
+2.5 \\
+0.7 \\
-1.0 \\
+0.2 \\
+1.0\end{array}$ & $\begin{array}{r}10.8 \\
9.9 \\
5.9 \\
11.3 \\
5.6 \\
6.5 \\
8.2 \\
6.2 \\
8.3\end{array}$ & $\begin{array}{c}14 \\
9 \cdot 2 \\
11 \\
5 \cdot 2 \\
18 \\
20 \\
9 \cdot 2 \\
8 \cdot 5 \\
13\end{array}$ & $\begin{array}{c}3.5 \\
9.3 \\
13 \\
<2.5 \\
5 \\
18 \\
3 \\
5.6 \\
5.4\end{array}$ \\
\hline & & & & & & $12 \pm 1 \cdot 6^{*}$ & $7 \cdot 3 \pm 1 \cdot 7^{*}$ \\
\hline
\end{tabular}

* Mean values $\pm \mathrm{SE}$ of mean.

Conversion: SI to traditional units-Serum prolactin $1 \mu \mathrm{g} / \mathrm{l}=1 \mathrm{ng} / \mathrm{ml}$ (reference range 3-16 $\mu \mathrm{g} / 1$ ); energy intake $1 \mathrm{MJ} \approx 239 \cdot 2 \mathrm{kcal}$. 


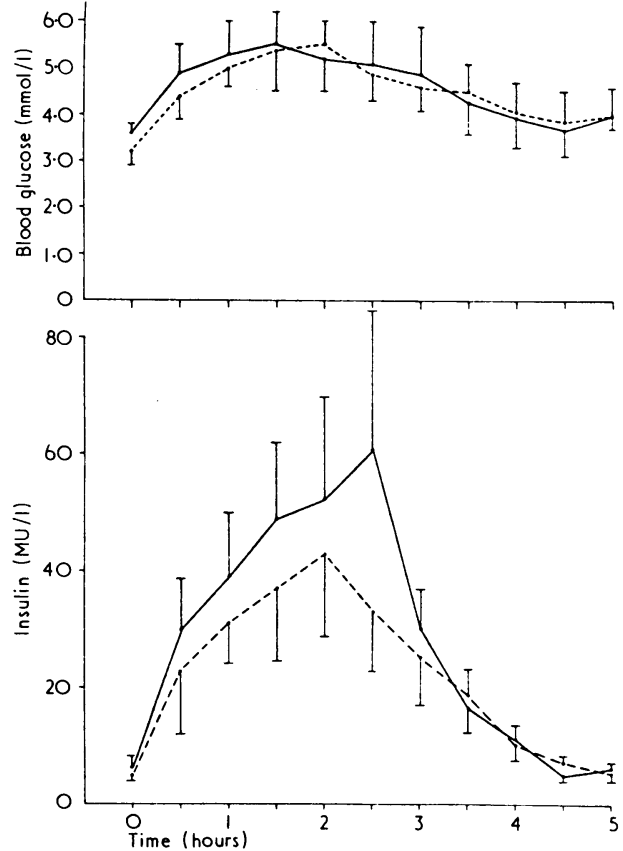

FIG 2-Mean ( \pm SE of mean) blood glucose and plasma insulin concentrations during oral glucose tolerance test in eight women patients with anorexia nervosa before (dashed line) and during (solid line) treatment with bromocriptine.

Conversion: SI to traditional units-Blood glucose $1 \mathrm{mmol} / \mathrm{l} \approx 18 \mathrm{mg} / 100 \mathrm{ml}$.

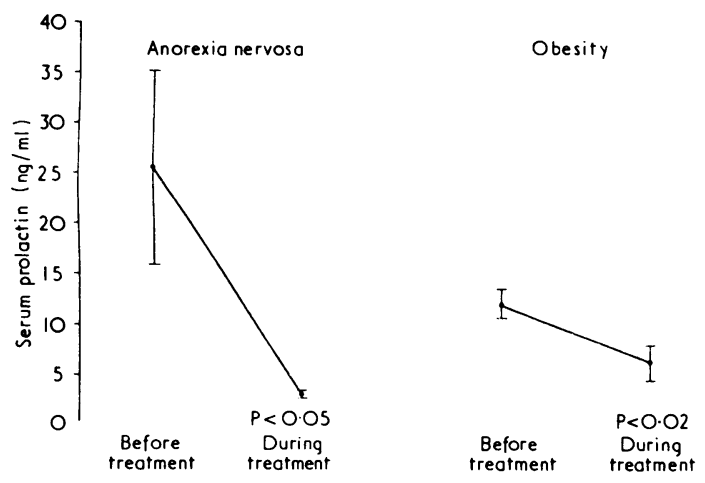

FIG 3-Mean ( \pm SE of mean) serum prolactin concentrations in eight female patients with anorexia nervosa and nine female patients with refractory obesity before and during treatment with bromocriptine $10 \mathrm{mg} /$ day.

One patient complained of slight nausea on starting treatment, but this soon disappeared. During treatment changes in weight were trivial and inconsistent (table I).

\section{OBESITY}

Figure 4 shows the mean values for plasma GH during the oral glucose tolerance test both before and during treatment with bromocriptine. In contrast to the anorexic patients we found no significant changes, the GH concentrations remaining suppressed throughout the study. The blood glucose and plasma insulin concentrations were also unaffected by bromocriptine either in individual patients or in the group as a whole (fig 4). The GH response to insulin-induced hypoglycaemia was unaltered by treatment with bromocriptine (fig 5), adequate hypoglycaemia (blood glucose $<2 \mathrm{mmol} / 1(36 \mathrm{mg} / 100 \mathrm{ml})$ ) being obtained in each case. Similarly, the plasma 11-OHCS response to hypoglycaemia was unaffected by bromocriptine (fig 5). Prolactin concentrations were normal in seven patients and marginally raised in two; the concentrations fell significantly during treatment in the group as a whole $(P<0.02$; table II and fig 3$)$.
After treatment with bromocriptine for three months, weight changes in the obese ranged from -2.4 to $2.5 \mathrm{~kg}$. Only two patients lost any weight (table II). All nine patients experienced some side effects, mainly nausea; in six patients this disappeared on continuing treatment. In two other patients the nausea persisted on increasing the dose above $5 \mathrm{mg} /$ day and another patient complained of lightheadedness that continued after increasing the dose to $10 \mathrm{mg}$. One patient complained of persistent yawning on a dose of $5 \mathrm{mg} /$ day, but this disappeared with continuing treatment.

\section{Discussion}

In anorexia nervosa, as in acromegaly, bromocriptine reduced the raised $\mathrm{GH}$ concentrations occurring during the oral glucose tolerance test. This suggests that the hypothalamopituitary

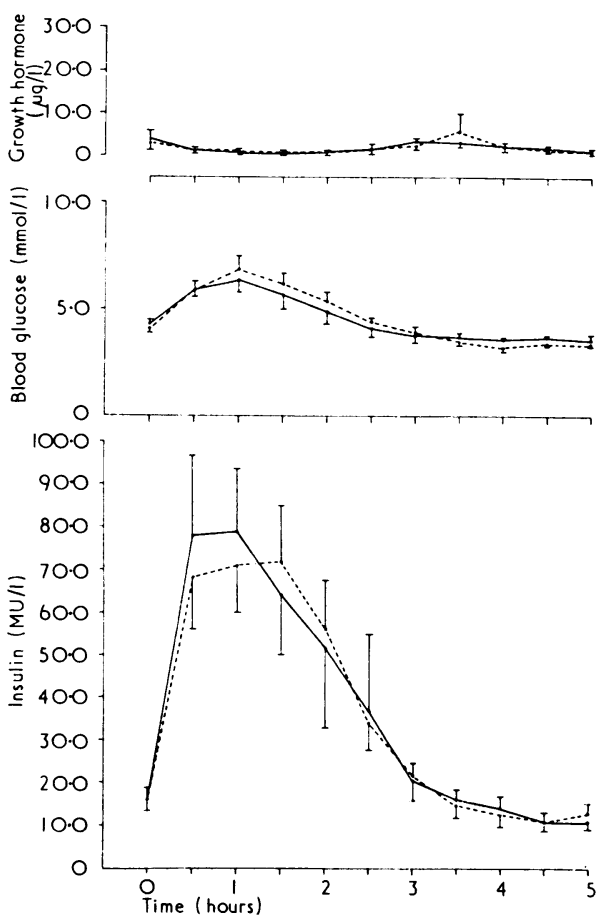

FIG 4-Mean ( + SE of mean) plasma growth hormone, blood glucose, and plasma insulin concentrations during an oral glucose tolerance test in nine women patients with refractory obesity before (dashed line) and during (solid line) treatment with bromocriptine $10 \mathrm{mg} /$ day.

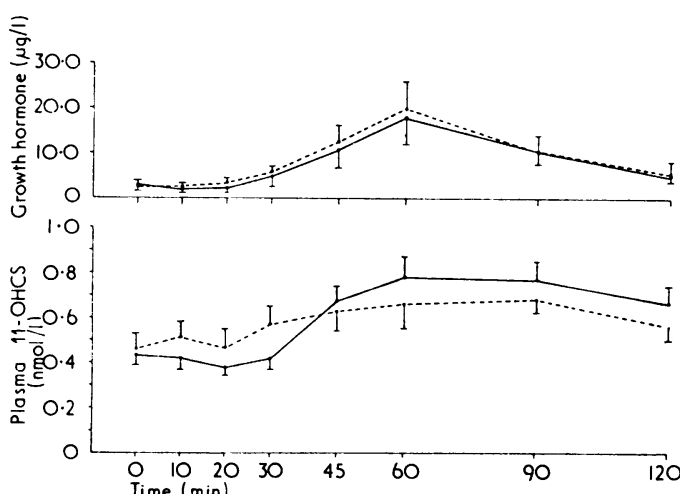

FIG 5-Mean ( \pm SE of mean) plasma growth hormone and 11-hydroxycorticosteroid (11-OHCS) concentrations during an insulin tolerance test in nine women patients with refractory obesity before (dashed line) and during (solid line) treatment with bromocriptine.

Conversion: SI to traditional units-Plasma 11-hydroxycorticosteroid $1 \mathrm{nmol} / \mathrm{l} \approx 0.04 \mu \mathrm{g} / 100 \mathrm{ml}$ 
pathways that stimulate or suppress $\mathrm{GH}$ release in these two conditions may be alike, and may therefore be similarly modified by bromocriptine. Alternatively, a main site of action of bromocriptine may be the pituitary, where the cells may respond to the drug in the same way in anorexia nervosa as in the adenoma of the patient with acromegaly. In the obese patients bromocriptine did not alter the response to the oral glucose tolerance test, GH concentrations being neither raised nor lowered. Any initial $\mathrm{GH}$ release after bromocriptine might be short-lived, and might not occur with continuous administration.

The failure of bromocriptine to modify the $\mathrm{GH}$ response to insulin-induced hypoglycaemia is in keeping with the suggestion that this response is largely serotonergic, as it is partially inhibited by serotonin antagonists. ${ }^{16}$ Similar serotonergic mechanisms have been shown in the corticotrophin response to insulin hypoglycaemia, ${ }^{1-}$ and the rise in plasma 11-OHCS was also unaltered during bromocriptine treatment.

Prolactin concentrations were reduced during treatment in both groups of patients, the anorexic patients as a group having a higher concentration before treatment than the obese patients. The dose of $10 \mathrm{mg}$ bromocriptine daily was not only ineffective in reducing the weight of patients with refractory obesity, but the side effects were also more troublesome than those experienced by the patients with anorexia nervosa.

Although no significant weight changes occurred in the anorexic patients over a period of two weeks' treatment, the effect of bromocriptine on GH release suggests that the drug merits further consideration in this disorder. Amenorrhoea in anorexia nervosa, which precedes weight loss in many patients, ${ }^{4}$ might be related to hyperprolactinaemia. Such an association, together with the known effect of bromocriptine on hyperprolactinaemia, would justify further study in this type of patient, particularly if patients could be identified as anorexic before their abnormal eating habits and behaviour had become firmly established. Our findings, however, do not justify further use of the drug in obesity.

We thank our nursing, dietitian, and technician colleagues for help with this study, and Dr D B Horn for undertaking some of the assays in the department of clinical chemistry.

\section{References}

${ }^{1}$ Camanni, F, et al, fournal of Clinical Endocrinology and Metabolism, $1975,40,363$.

2 Thorner, M O, et al, British Medical fournal, 1975, 1, 299.

${ }^{3}$ Sachdev, Y, et al, Lancet, 1975, 2, 1164

Kanis, J A, et al, Quarterly fournal of Medicine, 1974, 43, 321.

${ }^{5}$ Hunter, W M, Friend, J A R, and Strong, J A, fournal of Endocrinology, 1966, 34, 139.

${ }^{6}$ Baird, J D, in Symposium on Anorexia and Obesity, p 83. Royal College of Physicians of Edinburgh, 1973.

${ }^{7}$ Beaumont, P J V, et al, Psychological Medicine, 1974, 4, 219.

${ }^{*}$ Franks, S, et al, Clinical Endocrinology, 1975, 4, 597.

9 Travaglini, P, et al, Acta Endocrinologica, 1976, 81, 252

10 Thorner, M O, et al, British Medical fournal, 1974, 2, 419.

${ }^{11}$ Hill, J B, and Kessler, G, Fournal of Laboratory and Clinical Medicine, 1961, 57, 970 .

12 Mattingly, D, fournal of Clinical Pathology, 1962, 15, 374.

13 Schalch, D S, Parker, M L, Nature, 1964, 103, 1141

${ }^{14}$ Hales, C N, and Randle, P, fournal of Biochemistry, 1963, 88, 137.

15 Reuter, A M, et al, International fournal of Nuclear Medicine and Biology, $1976,3,21$.

${ }^{16}$ Bivens, C H, Lebovitz, $\mathrm{H}$ E, and Feldman, J M, New England fournal of Medicine, 1973, 289, 236.

1: Plank, J W, Bivens, C H, and Feldman, J M, Fournal of Clinical Endocrinology and Metabolism, 1974, 38, 836.

\title{
Circulating immune complexes after repeated halothane anaesthesia
}

\author{
B D WILliams, N White, P L AMLOT, J SLANEY, P A TOSELAND
}

British Medical fournal, 1977, 2, 159-162

\section{Summary}

A patient developed hepatitis after receiving three halothane anaesthetics in 22 days. Twenty-four hours after the onset of jaundice she developed an acute serum sickness syndrome with polyarthralgia, proteinuria, and transient impairment of renal function. Serum concentrations of complement components $\mathrm{C1q}, \mathrm{C4}$, and

Royal Postgraduate Medical School, Hammersmith Hospital, London W12 0HS

B D WILLIAMS, MSC, MRCP, lecturer, department of immunology

National Hospital for Nervous Diseases, Queen Square, London WC1

N WHITE, BSC, MRCP, senior house officer

Guy's Hospital, London SE1 9RT

P L AMLOT, MB, MRCP, lecturer, department of medicine

J SLANEY, AIMLT, technician, department of medicine

P A TOSELAND, BSC, PHD, principal biochemist
C3 were substantially reduced, and immune complexes capable of activating the complement system via the classical pathway were present in the serum and synovial fluid. A metabolite of halothane was associated with these complexes. Fourteen months after exposure to halothane her lymphocytes were stimulated in vitro by this metabolite. The conditions under which stimulation occurred were unusual-namely, a $7 S$ fraction of the serum, presumably IgG, was necessary. Our results provide strong evidence that halothane may be immunogenic and that its immunogenicity is dependent on the noncovalent binding of one of its metabolites to plasma proteins.

\section{Introduction}

Although the incidence of jaundice after halothane anaesthesia is believed to be low,' there is continuing controversy whether a direct association exists between repeated exposure to halothane and postoperative hepatic necrosis. ${ }^{2}$ The mechanisms producing liver damage are not known, although it is widely held to be the result of a delayed hypersensitivity response to halothane or one of its metabolites. 